\title{
Intravitreal vs. subtenon triamcinolone acetonide for the treatment of diabetic cystoid macular edema Mauro Cellini* ${ }^{*}$, Alberto Pazzaglia ${ }^{\dagger}$, Eugenio Zamparini ${ }^{\dagger}$, Pietro Leonetti $^{\dagger}$ and Emilio C Campos ${ }^{\dagger}$
}

Address: Department of Surgery and Transplant "A. Valsalva", Ophthalmology Service (Chief: Prof. E.C. Campos), University of Bologna, Italy Email: Mauro Cellini* - mauro.cellini@unibo.it; Alberto Pazzaglia - angela.ungarelli@unibo.it; Eugenio Zamparini - ezampar@tin.it; Pietro Leonetti - pietro.leonetti@yahoo.it; Emilio C Campos - emilio.campos@unibo.it

${ }^{*}$ Corresponding author †Equal contributors

Published: 17 March 2008

BMC Ophthalmology 2008, 8:5 doi:10.1/86//47|-24/5-8-5
Received: 4 November 2007

Accepted: 17 March 2008

This article is available from: http://www.biomedcentral.com/I47I-24I5/8/5

(C) 2008 Cellini et al; licensee BioMed Central Ltd.

This is an Open Access article distributed under the terms of the Creative Commons Attribution License (http://creativecommons.org/licenses/by/2.0), which permits unrestricted use, distribution, and reproduction in any medium, provided the original work is properly cited.

\begin{abstract}
Background: To assess the efficacy of the intravitreal (IVT) injection of Triamcinolone Acetonide (TA) as compared to posterior subtenon (SBT) capsule injection for the treatment of cystoid diabetic macular edema.

Methods: Fourteen patients with type II diabetes mellitus and on insulin treatment, presenting diffuse cystoid macular edema were recruited. Before TA injection all focal lakes were treated by laser photocoagulation. In the same patients one eye was assigned to $4 \mathrm{mg}$ IVT injection of TA and the fellow eye was then treated with $40 \mathrm{mg}$ SBT injection of TA. Before and one, three and six months after treatment we measured visual acuity with ETDRS chart as well as thickness of the macula with optical coherence tomography (OCT) and intraocular pressure (IOP).
\end{abstract}

Results: The eyes treated with an IVT injection displayed significant improvement in visual acuity, both after one $(0.49 \mathrm{I} \pm 0.070 ; p<0.00 \mathrm{I})$ and three months $(0.500 \pm 0.089 ; \mathrm{p}<0.00 \mathrm{I})$ of treatment. Significant improvement was displayed also in eyes treated with an SBT injection, again after one $(0.455 \pm 0.069 ; p<0.001)$ and three months $(0.427 \pm 0.065 ; p<0.00 \mathrm{I})$. The difference between an IVT injection $(0.809 \pm 0.083)$ and SBT injection $(0.460 \pm 0.072)$ becomes significant six months after the treatment $(p<0.001)$.

Macular thickness of the eyes treated with IVT injection was significantly reduced both after one $(222.7 \pm 13.4$ $\mu \mathrm{m} ; \mathrm{p}<0.00 \mathrm{I})$ and after three months $(228.1 \pm 10.6 \mu \mathrm{m} ; \mathrm{p}<0.00 \mathrm{I})$ of treatment. The eyes treated with SBT injection displayed significant improvement after one $(220.1 \pm 15.1 \mu \mathrm{m} ; \mathrm{p}<0.00 \mathrm{I})$ and after three months $(23 \mathrm{I} .3$ $\pm 10.9 \mu \mathrm{m} ; \mathrm{p}<0.00 \mathrm{I})$. The difference between the eyes treated with IVT injection $(385.2 \pm \mathrm{II} .3 \mu \mathrm{m})$ and those treated with SBT injection $(235.4 \pm 8.7 \mu \mathrm{m})$ becomes significant six months after the treatment $(\mathrm{P}<0.00 \mathrm{I})$.

Intraocular pressure of the eyes treated with IVT injection significantly increased after one month $(17.7 \pm 1.1 \mathrm{~mm} /$ $\mathrm{Hg} ; \mathrm{p}<0.020)$, three $(18.2 \pm 1.2 \mathrm{~mm} / \mathrm{Hg} ; \mathrm{p}<0.003)$ and six month $(18.1 \pm 1.3 \mathrm{~mm} / \mathrm{Hg} ; \mathrm{p}<0.007)$ when compared to baseline value $(16.1 \pm 1.402 \mathrm{~mm} / \mathrm{Hg})$. In the SBT injection eyes we didn't display a significant increase of intraocular pressure after one $(16.4 \pm 1.2 \mathrm{~mm} / \mathrm{Hg} ; \mathrm{p}<0.450)$, three $(16.3 \pm 1.1 \mathrm{~mm} / \mathrm{Hg} ; \mathrm{p}<0.630)$ and six months $(16.2 \pm 1.1 \mathrm{~mm} / \mathrm{Hg} ; \mathrm{p}<0.720)$ when compared to baseline value $(16.2 \pm 1.3 \mathrm{~mm} / \mathrm{Hg})$.

Conclusion: The parabulbar subtenon approach can be considered a valid alternative to the intravitreal injection.

Trial registration: Current Controlled Trials ISRCTN67086909 


\section{Background}

Diabetic macular edema is one of the leading causes of diabetes induced visual impairment and affects one third of diabetic patients with disease duration of twenty years or more [1]. Many studies, including the Early Treatment Diabetic Retinopathy Study (ETDRS) have demonstrated that macular photocoagulation is effective for the treatment of macular edema [2,3] but does not usually restore vision loss occurring before treatment $[2,4]$. Laser photocoagulation, however, only has a moderate effect in preventing further visual loss in about $50 \%$ of patients $[2,4]$.

Recently, there have been many reports of the effectiveness of intravitreal triamcinolone acetonide (TA) for the treatment of diffuse macular edema, refractory to laser treatment $[5,6]$.

Intravitreal triamcinolone injections are however associated with many ocular complications (i.e. ocular hypertone, endophthalmitis, intraocular hemorrhages, detachment of the retina) $[5,7,6,8,9]$. Parabulbar subtenon injection of steroids appears to offer a good alternative for the treatment of diabetic macular edema and intermediate uveitis $[10,11]$. This approach is less invasive than intravitreal injection and may deliver equivalent therapeutic quantities of TA to the retina [12].

The purpose of this study was to assess the efficacy of the intravitreal (IVT) injection of TA as compared to posterior subtenon (SBT) capsule injection for the treatment of cystoid diabetic macular edema.

\section{Methods}

A total of 14 patients (28 eyes) were treated, 10 males and 4 females, aged between 61 and 74 years (mean 68.3), with type II diabetes mellitus and on insulin treatment.

All patients were phakic and showed a diffuse macular edema without retinal-vitreous traction. The patients were recruited among patients treated by the Ophthalmology Service of the S. Orsola-Malpighi Hospital, Bologna. Before enrolment, patients were informed of the procedures and the aim of the study and they signed a written consent form. The institutional ethics committee of the S. Orsola-Malpighi Hospital also approved the study. In all the patients the best corrected logarithm of the minimum angle of resolution (logMAR) visual acuity was assessed using the Early Treatment Diabetic Retinopathy Study (ETDRS) chart, as well as intraocular pressure (IOP) applanation tonometry and anterior and posterior segment biomicroscopy. Macular edema was defined by central thickening revealed with biomicroscopy using a 78diopter non-contact lens and by diffuse fluorescein leakage on fluorescein angiography (FA). Macular thickness was measured by optical coherence tomography (OCT).
All focal lakes previously were treated by laser photocoagulation.

Exclusion criteria included history of uveitis episodes, previous ocular surgery, glaucoma and ocular hypertension.

In the same patients one eye was assigned with $\mathrm{a}$, random method generated by a computer to intravitreal (IVT) injection of TA. One week after the IVT treatment of the first eye, and after excluding the appearance of complications (i.e. hypertone, vitreous hemorrhage, endophthalmitis), the fellow eye was then treated with subtenon (SBT) injection of TA. Two days before the IVT injection of TA, to avoid post-operative hypertone, the patients were prescribed a systemic treatment with acetazolamide, 250 mg two times daily.

For the IVT injection, the patient was placed supine and we performed a surface anesthesia with topical $4 \%$ carbocaine followed by a preparation with $5 \%$ povidone iodine. A volume of $0.1 \mathrm{ml}$ containing $4 \mathrm{mg}$ preservativefree TA (Kenacort, Bristol-Myers Squibb, Sermoneta, Italy) was injected through the inferotemporal pars-plana (4.0 $\mathrm{mm}$ posterior to the limbus) using a 30-gauge needle. Indirect ophthalmoscopy was used to confirm correct intravitreal localization of the suspension. After the injection topical $0.3 \%$ Netilmicin ointment was prescribed.

For the posterior SBT injection, the patient was placed supine and after topical $0.4 \%$ oxybuprocaine surface anesthesia a $1 \mathrm{ml}$ of a $40 \mathrm{mg} / \mathrm{ml}$ of triamcinolone acetonide (Kenacort, Bristol-Myers Squibb, Sermoneta, Italy) was given in the inferotemporal quadrant using a 27gauge needle on $2.5-\mathrm{ml}$ syringe. The patients were direct to look in the extreme superonasal field of gaze. The conjunctiva and the Tenon's capsule were penetrated with the bevel of the needle toward the globe. The needle was advanced toward the macular area, taking care to remain in contact with the globe until the hub was firmly pressed against the conjunctival fornix and then the corticosteroid was slowly injected. After injection topical $0.3 \%$ Netilmicin ointment was prescribed.

For each patient in the group of SBT a B-scan examination was performed before and immediately after the injection to show the lucency in subtenon space representing the repository triamcinolone acetonide just in the macular area (Fig 1).

Subsequently, one, three and six months after treatment visual acuity and IOP were measured in the patients as well as thickness of the retinal macula with OCT.

The data were statistically evaluated using the Wilcoxon signed rank test and a $\mathrm{p}<0.05$ was considered significant. 

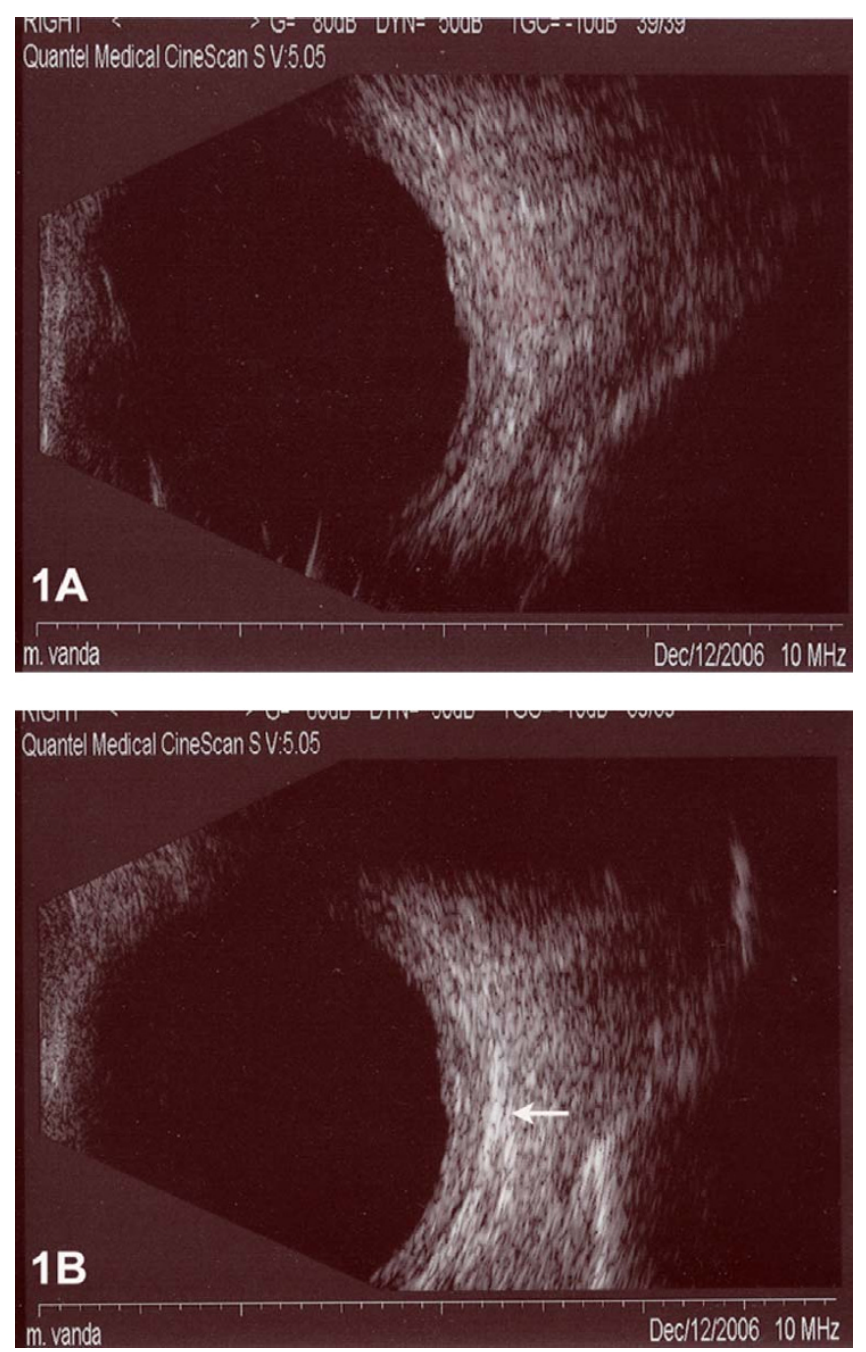

\section{Figure I}

Echographic images before and after subtenon triamcinolone injection. Echographic B-scan image before (A) and after (B) posterior subtenon triamcinolone acetonide injection where the lucency (white arrow) representing repository corticosteroid.

Data are presented as means \pm standard deviation (SD). The analysis was performed using SSI (version 11, Systat Software Inc., San Jose, California, USA) for Macintosh.

\section{Results}

The mean visual acuity before triamcinolone acetonide injection and after one, three and six months after are showed in Table 1 . The eyes treated with an IVT injection displayed significant improvement in visual acuity, both after one month $(0.491 \pm 0.070 ; \mathrm{p}<0.001)$ and after three months $(0.500 \pm 0.089 ; \mathrm{p}<0.001)$ of treatment when compared to the baseline values $(0.836 \pm 0.112)$. Significant improvement was displayed also in eyes treated with an SBT injection, again after one month $(0.455 \pm 0.069 ; \mathrm{p}$
$<0.001)$ and after three months $(0.427 \pm 0.065 ; \mathrm{p}<$ $0.001)$ when compared to the baseline values $(0.864 \pm$ $0.103)$. The difference of visual acuity between eyes treated with an IVT injection and those treated with an SBT injection becomes significant six months after the treatment $(\mathrm{p}<0.001)$. The eyes treated with IVT in fact display significant worsening of visual acuity $(0.809 \pm$ 0.083 ) whereas eyes treated with SBT maintain visual acuity improvement $(0.460 \pm 0.072)$.

The macular thickness before triamcinolone acetonide injection and after one, three and six months are showed in Table 2. The macular thickening of the eyes treated with IVT injection is concerned, thickness was significantly reduced both after one month $(222.7 \pm 13.4 \mu \mathrm{m} ; \mathrm{p}<$ $0.001)$ and after three months $(228.1 \pm 10.6 \mu \mathrm{m} ; \mathrm{p}<0.01)$ when compared to the baseline values $386.3 \pm 12.4 \mu \mathrm{m}$. The eyes treated with SBT injections displayed significant improvement after one month $(220.1 \pm 15.1 \mu \mathrm{m} ; \mathrm{p}<$ $0.001)$ and after three months $(231.3 \pm 10.9 \mu \mathrm{m} ; \mathrm{p}<$ 0.001 ) of treatment when compared to the baseline values of $384.1 \pm 18.9 \mu \mathrm{m}$. Here too the difference in retinal macular thickness of the eyes treated with IVT $(385.2 \pm 11.3$ $\mu \mathrm{m})$ and those treated with SBT $(235.4 \pm 8.7 \mu \mathrm{m})$ becomes significant six months after the treatment ( $\mathrm{p}<$ $0.001)$. Fig 2 illustrates the changes in the OCT images of a representative patient in the SBT injection group.

The mean intraocular pressure before triamcinolone acetonide injection and after one, three and six months are showed in Table 3 . The IOP of the eyes treated with IVT injection was significantly increased after one month $(17.7 \pm 1.1 \mathrm{~mm} / \mathrm{Hg} ; \mathrm{p}<0.020)$, three months $(18.2 \pm 1.2$ $\mathrm{mm} / \mathrm{Hg} ; \mathrm{p}<0.003)$ and six months $(18.1 \pm 1.320 \mathrm{~mm} /$ $\mathrm{Hg}$; $\mathrm{p}<0.007)$ when compared to baseline value $(16.1 \pm$ $1.4 \mathrm{~mm} / \mathrm{Hg}$ ) but none glaucoma medication was needed to control the IOP. The eyes treated with SBT injection displayed not significant increase of the IOP not only after one month $(16.4 \pm 1.2 \mathrm{~mm} / \mathrm{Hg} ; \mathrm{p}<0.450)$ but also after three $(16.3 \pm 1.1 \mathrm{~mm} / \mathrm{Hg} ; \mathrm{p}<0.630)$ and six months $(16.2 \pm 1.1 \mathrm{~mm} / \mathrm{Hg} ; \mathrm{p}<0.720)$ when compared to baseline value $(16.2 \pm 1.3 \mathrm{~mm} / \mathrm{Hg})$. The difference of IOP between eyes treated with an IVT injection and those

Table I: Visual acuity before and after IVT and SBT triamcinolone injection. Visual acuity with log/MAR resolution in the intravitreal and posterior subtenon injected eyes at baseline and at I, 3 and 6 months after triamcinolone acetonide injection.

\begin{tabular}{cccc}
\hline & IVT Visual Acuity & SBT Visual Acuity & $P<0.05$ \\
\hline Baseline & $0.836 \pm 0.112$ & $0.864 \pm 0.103$ & 0.625 \\
I month & $0.491 \pm 0.070$ & $0.455 \pm 0.069$ & 0.161 \\
3 months & $0.500 \pm 0.089$ & $0.427 \pm 0.065$ & 0.070 \\
6 months & $0.809 \pm 0.083$ & $0.460 \pm 0.072$ & 0.001
\end{tabular}




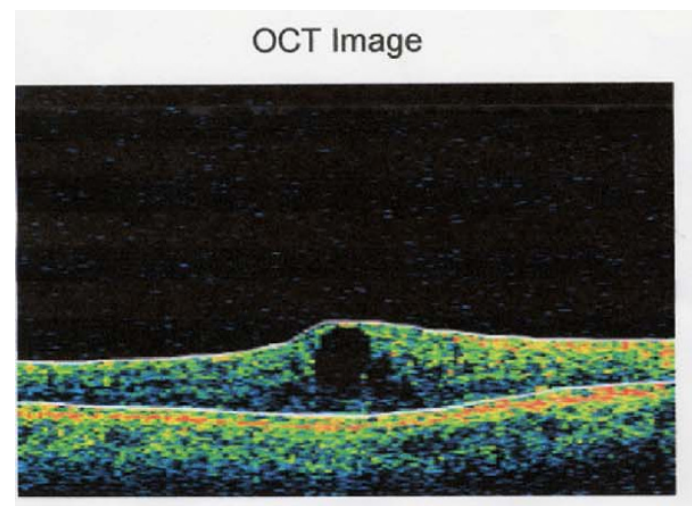

Fundus Image
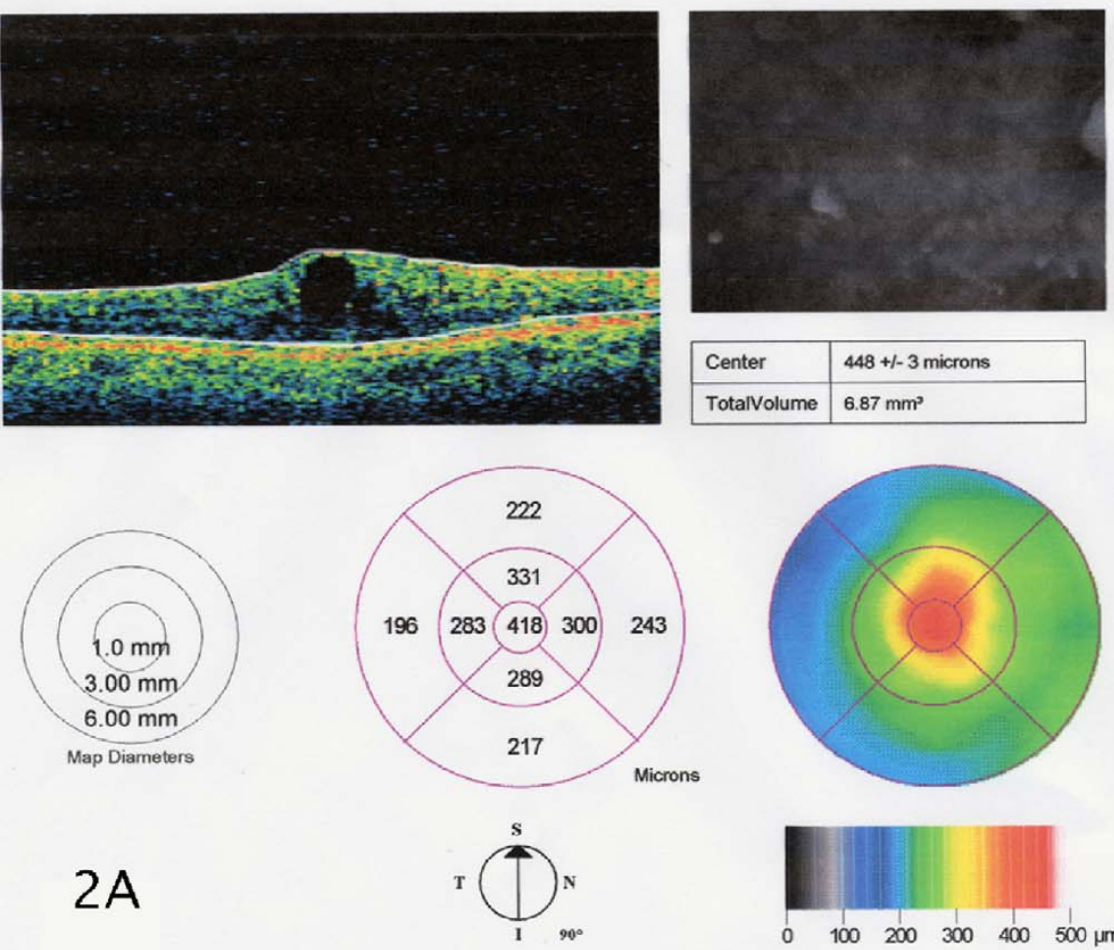

OCT Image
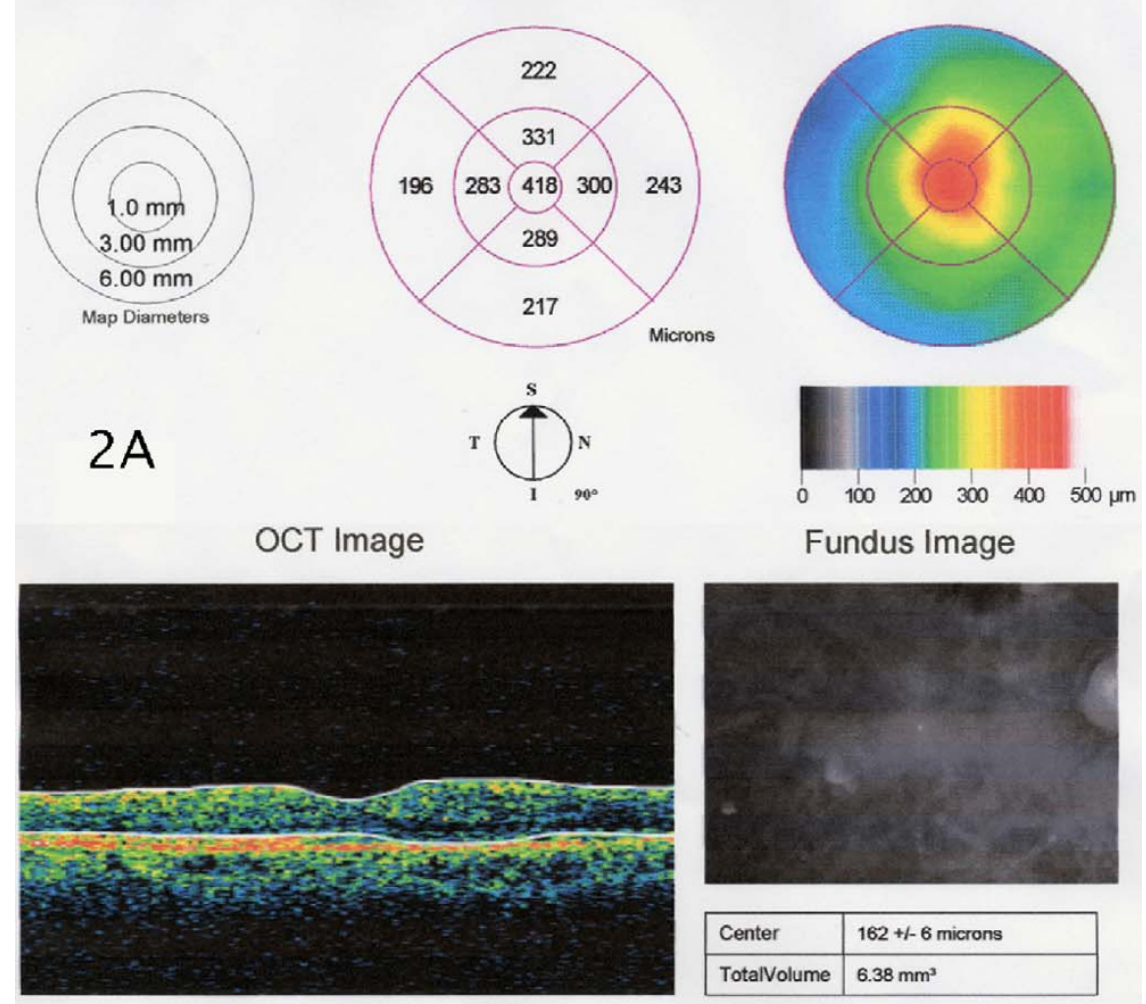

Fundus Image
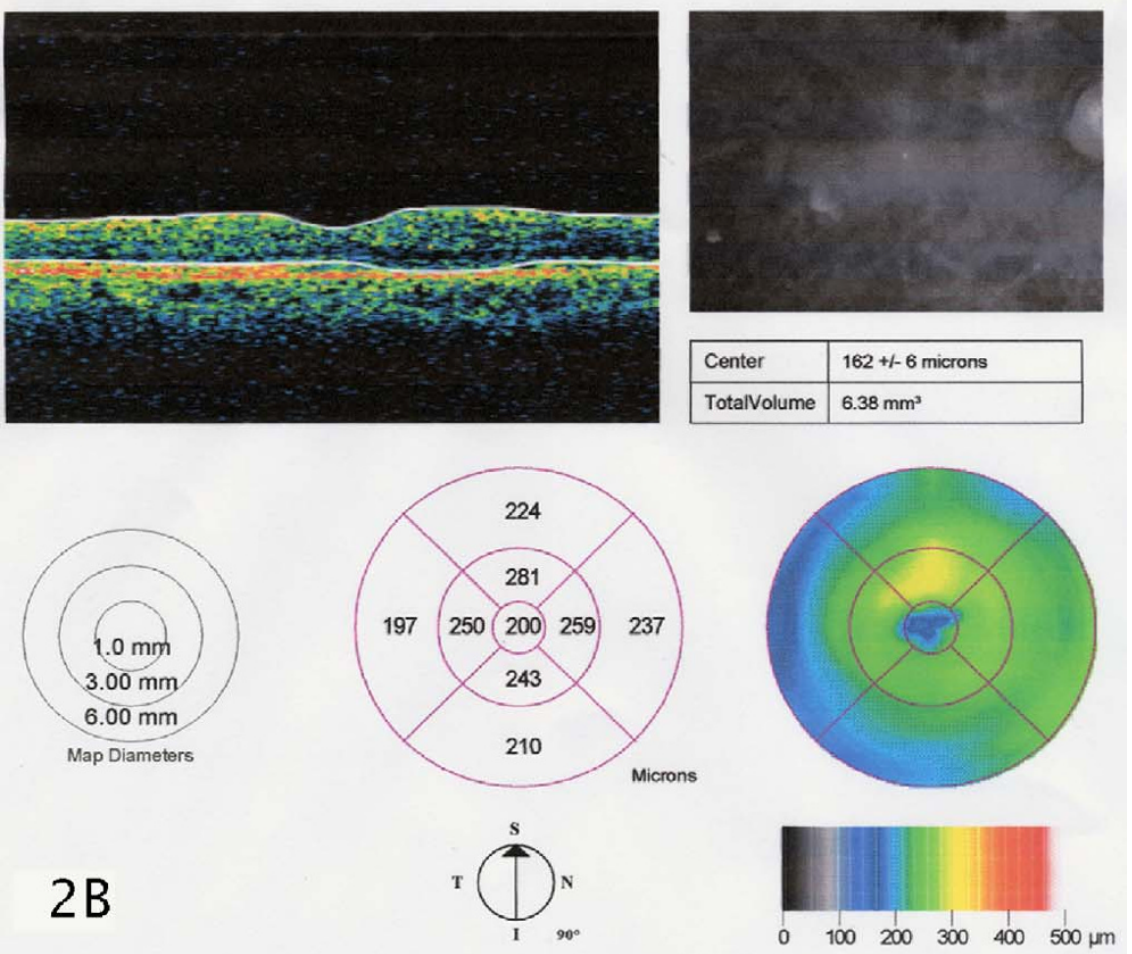

Figure 2

OCT images before and after subtenon triamcinolone injection. Optical coherence tomography map of diabetic cystoid macular edema before (A) and six months after (B) posterior subtenon triamcinolone acetonide injection. 
Table 2: Macular thickness before and after IVT and SBT triamcinolone injection. Central macular thickness $(\mu \mathrm{m})$ in the intravitreal and posterior subtenon injected eyes at baseline and at I, 3 and 6 months after triamcinolone acetonide injection.

\begin{tabular}{lccc}
\hline & IVT Macular Thickness & SBT Macular Thickness & $P<0.05$ \\
\hline Baseline & $386.3 \pm 12.4$ & $384.1 \pm 18.9$ & 0.721 \\
I month & $222.7 \pm 13.4$ & $220.1 \pm 15.1$ & 0.625 \\
3 months & $228.1 \pm 10.6$ & $231.3 \pm 10.9$ & 0.580 \\
6 months & $385.2 \pm 11.3$ & $235.4 \pm 8.7$ & 0.001 \\
\hline
\end{tabular}

treated with an SBT injection becomes significant at three $(\mathrm{p}<0.026)$ and six $(\mathrm{p}<0.030)$ months.

\section{Discussion}

This study demonstrates that three months after the intravitreal injection of TA and the subtenon injection of TA there is a statistically significant improvement in visual acuity and an equally significant reduction in retinal thickness. Six months after IVT the patients presented a recurrence of macular edema with loss of visual acuity whereas six months after SBT injection retinal thickness and visual acuity remained stable. After one, three and six months we observed a statistically significant rise of the IOP in the eyes treated with IVT injection whereas in the SBT injection group, no statistically significant variations of the IOP were found. None of patients developed cataract or needed anti-glaucoma drugs during the follow-up.

Macular edema is the main cause of loss of visual acuity in diabetic patients $[13,14]$. It may occur at any stage of the retinal disorder and is the most common cause of sight reductions in these subjects.

In the edema, the hemato-retinal barrier is damaged by an alteration in the tight junction between the retinal capillary endothelial cells and the pigmented epithelial cells with the consequent leakage of water and electrolytes in the retinal tissue $[3,15-17]$.

As has been seen in numerous studies, including the Early Treatment Diabetic Retinopathy Study (ETDRS), macular photocoagulative treatment is effective in the treatment of clinically important macular edema $[2,18,3]$.

Table 3: Intraocular pressure before and after IVT and SBT triamcinolone injection. Intraocular pressure $(\mathrm{mm} / \mathrm{Hg})$ in the intravitreal posterior subtenon and injected eyes at baseline and at I, 3 and 6 months after triamcinolone acetonide injection.

\begin{tabular}{llll}
\hline & IVT-IOP & SBT-IOP & $\mathrm{P}<0.05$ \\
\hline Baseline & $16.1 \pm 1.4$ & $16.2 \pm 1.3$ & 0.140 \\
I month & $17.7 \pm 1.1$ & $16.4 \pm 1.2$ & 0.062 \\
3 months & $18.2 \pm 1.2$ & $16.3 \pm 1.1$ & 0.026 \\
6 months & $18.1 \pm 1.3$ & $16.2 \pm 1.1$ & 0.030
\end{tabular}

Thus laser photocoagulation for macular edema, although successful in blocking further visual loss in 50\% of patients, is unable to restore visual loss occurring prior to treatment $[2,4]$. Moreover, laser photocoagulation is not very effective in eyes with diffuse macular edema $[19,20]$.

The extent of the restoration of the hemato-retinal barrier functioning following laser treatment is debated as many studies indicate an increase in the edema following laser photocoagulation [20-22] probably as a result of the release of proinflammatory molecules. Indeed, the initial clinical pattern of diabetic retinopathy, with vasodilatation, increased blood flow, tissue edema and an increase in the vascular permeability presents the characteristics of chronic inflammation. This hypothesis is supported by recent studies, which have highlighted the appearance of leukostasis in diabetes [23] with adhesion of activated molecules to the endothelium [24], increased production of prostacyclin [25], vascular endothelial growth factor (VEGF) and macrophagic cellular component [26].

Further support for the thesis of inflammation as one of the causes of onset of diabetic retinopathy is provided by experimental studies in animals which demonstrate how hyperglycemias not only causes an increase in the production of cycloxygenase-2 (COX2), through the activation of protein-kinase (PKC) $[27,28]$, but also in prostaglandin synthetase (PGIS) [29] a specific enzyme in the synthesis of prostaglandin PGI2 [30]. Furthermore, recent studies have confirmed the important role of COX2 and the prostanoids in the onset of renal damage in patients with impaired glycemic control.

The fall in the prostacyclin levels only occurs in the advanced stage of diabetic microangiopathy. This is confirmed not only by the reduction in the blood PGI2 levels but also by the reduction in the PGE values observed at a vitreous level during proliferative diabetic retinopathy [31].

All these experimental and clinical data confirm the involvement of pro-inflammatory molecules that also cause a subclinical increase in the aqueous humor cells in the early stages of diabetic retinopathy [32]. 
Recent studies have shown that intravitreal injections of TA have a positive effect on those forms of diabetic macular edema that are refractory to retinal laser treatment $[5,7,6]$. The use of corticosteroids for the treatment of retinal edema is linked to their capacity to inhibit the initial arachidonic acid cascade, to determine a down-regulation of the cytokines and to attenuate the tearing of the hemato-retinal barrier $[7,15,33]$.

The use of intravitreal TA is not however without risks $[6,12]$. The main complications are endophthalmitis, intraocular hemorrhages, detachment of the retina $[5,7,6,8,9]$ and possible increases in IOP in a percentage of cases varying from $20 \%$ to $80 \%[7,6,34,35]$. Finally, the intravitreal administration of corticosteroids is only effective for a few months [36], which means that it is necessary to repeat the injections at three-monthly intervals to maintain stability of the retinal macula.

The subtenon TA administration has already been used in the treatment of cystoid macular edema and intermediate uveitis $[10,11]$. This administration route is not considered ideal to obtain a therapeutic dose of cortisone at the level of the retina [37] although this opinion can be contested on the basis of the clinical results and the ultrasound investigations which demonstrate how a correct administration of the injection makes it possible to deposit the drug in the macular area [38-40].

The subtenon approach is clearly less invasive than the intravitreal one [39] although, here again, this commonly used method is not free of potential complications such as the accidental injection directly into the choroidal or retinal circulation, perforation of the ocular bulb, occlusion of the central retinal artery and cataract [39]. Other complications described are blepharoptosis, orbital fat atrophy, strabismus and conjunctival necrosis $[39,41]$. IOP is not increased by the use of this approach with the exception of steroid responder patients $[39,41]$.

This study has attempted to simplify the subtenon injection technique even further by using a 27 gauge needle, generally used for parabulbar anesthetics in cataract surgery. This approach made it possible to administer the injection without having to create a surgical opening in the conjunctiva to access the subtenon space, thus improving patient compliance with this therapy. When we use the subtenon approach for TA injection it is very important to make a careful echographic examination to determine the correct location near the macula of the drug. Without echography we cannot determine whether an unsatisfactory therapeutic response is secondary to the disease process or to misdisplacement of the TA. We think that our good results with the SBT approach in this study is related to the correct placement of TA near the macular area displayed with the echographic images.

\section{Conclusion}

This study, although involving a limited number of selected patients, indicates how the eyes given a subtenon injection benefited from a more prolonged therapeutic efficacy of triamcinolone.

The subtenon approach, when the triamcinolone acetonide is correctly placed in the subtenon spaces, can be considered an easy, safe and valid alternative to the intravitreal injection.

\section{Competing interests}

The author(s) declare that they have no competing interests.

\section{Authors' contributions}

MC recruited the patient from the Retina Disease Service of the S. Orsola-Malpighi Hospital, he drafted the manuscript and performed the subtenon TA injection. AP performed the intravitreal TA injection. EZ reviewed the literature, PL examined the patient in the time and ECC review the manuscript. All authors read and approved the final manuscript.

\section{Acknowledgements}

This work was supported in part through University of Bologna (ECCMIUR ex-60\%), in part from a grant of the "Fondazione Banca del Monte di Bologna e Ravenna" and in part through a gift of the "Fondazione Cassa di Risparmio di Bologna".

The authors thank Mrs. Juliet Macan for English review of the manuscript.

\section{References}

I. Klein R, Klein BE, Moss SE: The Wisconsin epidemiologic study of diabetic retinopathy. IV. Diabetic macular edema. Ophthalmology 1984, 9 I: | 464- | 474.

2. Early Treatment Diabetic Retinopathy Study Research Group. Photocoagulation for diabetic macular edema. Early Treatment Diabetic Retinopathy Study report number I. Arch Ophthalmol 1985, 103:1796-1806.

3. Aiello LM: Perspectives on diabetic retinopathy. Am J Ophthalmol 2003, 136: I22-135.

4. Akduman L, Olk RJ: Laser photocoagulation of diabetic macular edema. Ophthalmic Surg Lasers 1997, 28:387-408.

5. Massin P, Audren F, Haouchine B: Intravitreal triamcinolone acetonide for diabetic diffuse macular edema: preliminary results of a prospective controlled trial. Ophthalmology 2004, III:2|8-24.

6. Jonas JB, Kreissig I, Sofker A, Degenring RF: Intravitreal injection of triamcinolone for diffuse diabetic macular edema. Arch Ophthalmol 2003, I 21:57-6I.

7. Martidis A, Duker JS, Greenberg PB: Intravitreal triamcinolone for refractory diabetic macular edema. Ophthalmology 2002, 109:920-927.

8. Moshfeghi DM, Kaiser PK, Scott IU: Acute endophthalmitis following intravitreal triamcinolone acetonide injection. $\mathrm{Am} J$ Ophthalmol 2003, 136:791-796.

9. Jonas JB, Kreissig I, Degenring R: Secondary chronic open-angle glaucoma after intravitreal triamcinolone acetonide. Arch Ophthalmol 2003, 121:729-730. 
10. Helm C], Holland GN: The effects of posterior subtenon injection of triamcinolone actetonide in patients with intermediate uveitis. Am J Ophthalmol 1995, I 20:55-64.

II. Thach $A B$, Dugel PU, Flindall RJ: A comparison of retrobulbar versus sub-Tenon's corticosteroid therapy for cystoid macular edema refractory to topical medications. Ophthalmology 1997, I 04:2003-2008.

12. Geroski DH, Edelhauser HF: Transcleral drug delivery for posterior segment disease. Adv Drug Deliv Rev 200I, 52:37-48.

13. Moss SE, Klein R, Klein BE: Ten-year incidence of visual loss in a diabetic population. Ophthalmology 1994, I0 I(6): I061-1070.

14. Moss SE, Klein R, Klein BE: The I4-year incidence of visual loss in a diabetic population. Ophthalmology 1998, I 05(6):998-1003.

I5. Aiello LP: The potential role of PTK beta in diabetic retinopathy and macular edema. Surv Ophthalmol 2002 47(suppl):S263-9.

16. Sander B, Larsen M, Moldow B, Lund-Andersen H: Diabetic macular edema: passive and active transport of fluorescein through the blood-retina barrier. Invest Ophthalmol Vis Sci 200I, 42:433-438.

17. Kent D, Vinores SA, Campochiaro PA: Macular edema: the role of soluble mediators. Br J Ophthalmol 2000, 84:542-545.

18. Early Treatment Diabetic Retinopathy Study Research Group. Treatment techniques and clinical guidelines for photocoagulation of diabetic macular edema. Early Treatment Diabetic Retinopathy Study report number 2. Ophthalmology 1987, 94:76I-774.

19. Lee CM, Olk Rj: Modified grid laser photocoagulation for diffuse macular edema: long-term visual results. Ophthalmology |99|, 98:1594-1602

20. Early Treatment Diabetic Retinopathy Study Research Group. Focal photocoagulation treatment of diabetic macular edema. Relationship of treatment effect to fluorescein angiographic and other retinal characteristics at baseline: ETDRS report no. I9. Arch Ophthalmol 1995, I I 3: I | 44- I I55.

21. Nanoka A, Kiryu J, Tsujikawa A: Inflammatory response after scatter laser photocoagulation in nonphotocoagulated retina. Invest Ophthalmol Vis Sci 2002, 43: I204-I209.

22. Hudson C, Flanagan JG, Turner GS: Correlation of a scanninig laser derived edema index and visual function following grid laser treatment for diabetic macular edema. $\mathrm{Br} J \mathrm{Ophthalmo}$ 2003, 87:455-46I.

23. Barouch FC, Miyamoto K, Allport JR: Integrin-mediated neutrophil adhesion and retinal leukostasis in diabetes. Invest Ophthamol Vis Sci 2000, 4I(5): I I53-1 I58.

24. Miyamoto E, Khosrof S, Bursell SE: Prevention of leukostasis and vascular leakage in streptozotocin-induced diabetic retinopathy via intercellular adhesion molecule-I inhibition. Proc Natl Acad Sci USA 1999, 96:10836-1084I.

25. Hata $Y$, Clermont $A$, Yamauchi T: Retinal expression. regulation. and functional bioactivity of prostacyclin-stimulating factor. J Clin Invest 2000, I 06:54 I-550.

26. Takagi H, Otani A, Kiryu J, Ogura $Y$ : New surgical approach for removing foveal hard exudates in diabetic macular edema. Ophthalmology 1999, I06:249-256.

27. Tesfamariam B, Brown ML, Cohen RA: Elevated glucose impairs endothelium-dependent relaxation by activating protein kinase C. J Clin Invest 1991, 87: 1643-1648.

28. Mayhan WG, Patel KP: Acute effects of glucose on reactivity of cerebral microcirculation: role of activation of protein kinase C. Am J Physiol 1995, 269(4): I I297- I I 302

29. Casentino F, De Paolis $P$, van der Loo B, Bachschmid M, Ullrich V Kouroedov A, Delli Gatti C, Joch H, Volpe M, Lüscher TF: High Glucose Causes Upregulation of Cyclooxygenase-2 and alters Prostanoid Profile in Human Endothelial Cells. Role of Protein Kinase C and Reactive Oxygen Species. Circulation 2003, 107:1017-1023.

30. Hara S, Miyata A, Yokoyama C: Isolation and molecular cloning of prostacyclin synthase from bovine endothelial cells. I Biol Chem 1994, 269:19897-19903.

31. Douros S, Phillips BA, Nadel A, Obstbaum SA: Human vitreal prostaglandin levels and proliferative diabetic retinopathy. Doc Ophthalmol 200I, I 03(I):27-34.

32. Cellini M, Baldi A, Bernabini B, Leonetti P, Campos EC: Diabetic retinopathy and laser flare cell-meter. It Ophthalmol Bull 2005, 84:95-102.
33. Wilson CA, Berkowitz BA, Sato Y: Treatment with intravitrea steroid reduces blood-retinal barrier breakdown due to retinal photocoagulation. Arch Ophthalmol 1992, I I 0: I I55- I I59.

34. Wingate RJ, Beaumont PE: Intravitreal triamcinolone and elevated intraocular pressure. Aust N Z J Ophthalmol 1999, 27:431-432

35. Smithen LM, Ober MD, Maranan L, Spaide RF: Intravitreal triamcinolone acetonide and intraocular pressure. Am J Ophthalmol 2004, I 38:740-743.

36. Beer PM, Bakri JS, Singh RJ: Intraocular concentration and pharmacokinetics of triamcinolone acetonide after a single intravitreal injection. Ophthalmology 2003, I I 0:68 |-686.

37. Inoue $\mathrm{M}$, Takeda $\mathrm{K}$, Morita $\mathrm{K}$ : Vitreous concentrations of triamcinolone acetonide in human eyes after intravitreal or subtenon injection. Am J Ophthalmol 2004, I 38: I046-1048.

38. Freeman WR, Green RL, Smith RE: Echographic localization of corticosteroids after periocular injection. Am J Ophthalmol 1987, 103:281-288.

39. Mueller AJ, Jian G, Banker AS: The effect of deep posterior subtenon injection of corticosteroids on intraocular pressure. Am J Ophthalmol 1998, I 25:158-163.

40. Thomas ER, Wang J, Ege E, Madsen R, Hainsworth DP: Intravitreal Triamcinolone Acetonide concentration after subtenon injection. Am J Ophthalmol 2006, I42:860-86I.

4I. Agrawal S, Agrawal J, Agrawal TP: Conjunctival ulceration following triamcinolone injection. Am J Ophthalmol 2003, I 36:539-540.

\section{Pre-publication history}

The pre-publication history for this paper can be accessed here:

http://www.biomedcentral.com/1471-2415/8/5/prepub

Publish with BioMed Central and every scientist can read your work free of charge

"BioMed Central will be the most significant development for disseminating the results of biomedical research in our lifetime. "

Sir Paul Nurse, Cancer Research UK

Your research papers will be:

- available free of charge to the entire biomedical community

- peer reviewed and published immediately upon acceptance

- cited in PubMed and archived on PubMed Central

- yours - you keep the copyright
BioMedcentral 